\title{
A rare cause of maternal hydronephrosis: Y-type partial duplicated ureter
}

\section{Maternal hidronefrozun nadir bir nedeni: Y-tip parsiyel duplike üreter}

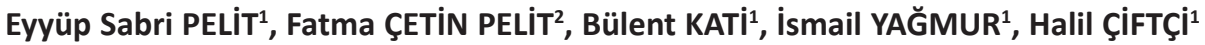

ABSTRACT

Gestational hydronephrosis is observed in $80-90 \%$ of the pregnancies due to the dilatation effect of progesterone hormone and mechanical compression of the uterus. (1) The common causes of the maternal hydronephrosis can be listed as physiological hydroureteronephrosis of the pregnancy, urolithiasis and genitourinary system anomalies (2). Ureteral duplication is a common anomaly, and observed in approximately 1 in 125 autopsized cases(3). Duplicated systems have 2 complete ureters with separate insertions into the lower urinary tract in $40 \%$ of the patients. The others have a partially duplicated system named as $Y$ configuration (4). To our best knowledge, it is a very rare case presentation in the current literature about the maternal hydronephrosis which is caused by bifid Y-type ureter.

Key words: Maternal hydronephrosis, duplicated ureter, DJ stent öz

Gestasyonel hidronefroz, uterusun mekanik kompresyonu ve progesteron hormonunun etkisi ile gebeliklerin \%80-90'nında gözlenir (1). Gebeliğin fizyolojik hidronefrozu, üriner sistem taşları ve anomalileri maternal hidronefrozun sık görülen nedenleri arasındadır (2). Üreter duplikasyonu sık görülen bir anomalidir ve otopsi serilerinde 125 kişide 1 görülmektedir (3). Duplike sistemlerin \%40'ı alt üriner sisteme ayrı ayrı bağlantısı olan komplet üreterler şeklindedir. Kalan kısım ise Y konfirigasyonu diye adlandırılan parsiyel duplike sistemlerdir. Güncel literatür tarandığında bu vaka bifid $Y$-tip üreterin neden olduğu maternal hidronefrozun anlatıldığı çok nadir bir olgu sunumudur.

Anahtar kelimeler: Maternal hidronefroz, duplike ureter, DJ stent

\section{INTRODUCTION}

Gestational hydronephrosis is observed in $80-90 \%$ of the pregnancy due to the dilatation effect of progesterone hormone and the secondary to mechanical compression of the uterus ${ }^{1}$. The common causes of the maternal hydronephrosis can be listed as physiological hydroureteronephrosis of the pregnancy, urolithiasis and genitourinary system anomalies ${ }^{2}$. Ureteral duplication is a common anomaly, observed in approximately 1 in 125 people on autopsy series ${ }^{3}$. Duplicated systems have 2 complete ureters with separate insertions into the lower urinary tract in $40 \%$ of the patients. The others have a partially duplicated system named as $Y$ configuration ${ }^{4}$. To our best knowledge, it is a very rare case presentation in the current literature about the maternal hydronephrosis which is caused by bifid Y-type ureter.

\section{CASE}

A 25-year-old (gravida 1, para 1) 29 week-pregnant woman was referred to our outpatient clinic with intractable left flank pain for 3 weeks. There was no remarkable medical complaint in her past medical history. She also complained of nausea and vomiting. On physical examination, costovertebral angle tenderness was present. Renal ultrasound scan showed grade 3 hydronephrosis in her left kidney and normal right kidney. Renal functions were within normal ranges, BUN was $17 \mathrm{mg} / \mathrm{dl}$ and creatinine $0.7 \mathrm{mg} / \mathrm{dl}$. Urine culture did not show any bacterial growth. We

Received: 06.03.2017

Accepted: 18.04 .2017

${ }^{1}$ Harran University School of Medicine Urology Department, Urfa, Turkey

${ }^{2}$ Special Academia Hospital Obstetric and Gynecology Clinic, Urfa Turkey

Yazışma adresi: Eyyüp Sabri Pelit, Harran University School of Medicine Urology Department, Urfa, Turkey

e-mail: dreyyupsabri@hotmail.com 
decided to insert DJ stent to relieve the symptoms of the patient. Under spinal anesthesia, guidewire was tried to pass with the aid of semi-rigid ureteroscopy (URS). However it did not pass beyond $2 \mathrm{~cm}$ distal to the left ureteral orifice. Then diagnostic ureteroscopy was performed. Bifid $Y$ configuration of the ureter was observed $2 \mathrm{~cm}$ distal to the left ureteral orifice (Fig 1). Diagnostic URS was performed through upper limb of duplicated system and lower limb of duplicated system respectively. We did not observe any anatomical problems that cause ureteral obstruction. Subsequently, we inserted a 2 DJ stent into the upper and lower limbs of duplicated Y ureter (Fig 1). Symptoms immediately resolved after DJ stent insertion, and the patient was not depending on medication for pain relief anymore. She was discharged from the hospital at $1^{\text {th }}$ postoperative day.

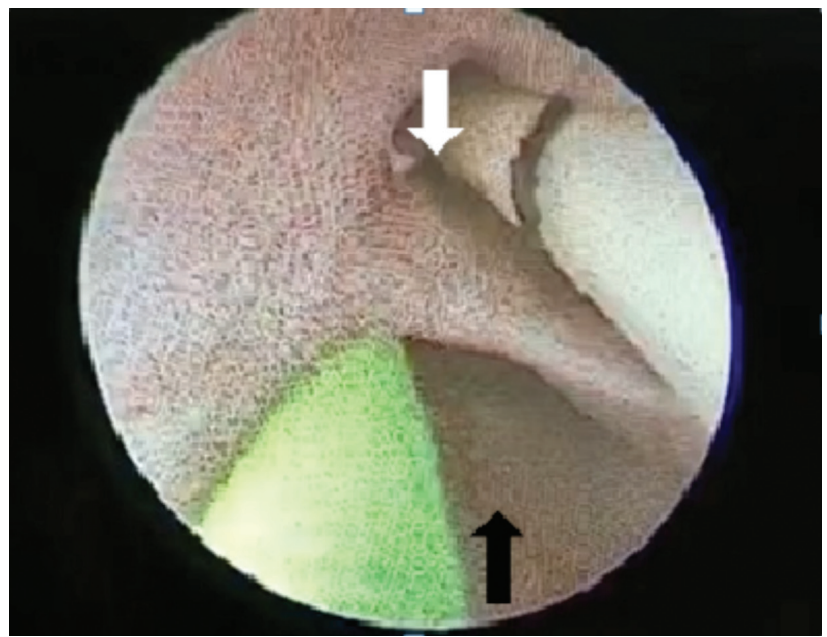

Figure 1. Bifid $Y$ configuration ureter, DJ stent was inserted to upper and lower limbs of duplicated $\mathrm{Y}$ ureter.

\section{DISCUSSION}

Maternal urinary tract problems are common during pregnancy. Physiological changes during the pregnancy can cause obstruction and stasis of urine which subsequently results in hydronephrosis in $90 \%$ of all pregnant women ${ }^{5}$. Hydronephrosis during pregnancy is observed mostly in the right kidney and becomes symptomatic in less than $3 \%$ of the cases ${ }^{1}$. The most common cause of hydronephrosis in pregnancy is due to the physiological changes. On the other hand, urolithiasis, urinary system anomalies or spontaneous rupture of the renal pelvis may cause hydronephrosis during the pregnancy ${ }^{6-7}$. In our case cause of the hydronephrosis was $Y$ type bifid ureter which is a common congenital collecting system anomaly.

Duplicated ureter is a congenital disorder, in that the embryological origin of the ureter splits into 2 limbs resulting in two ureters draining a single kidney. It is the most common renal abnormality. Ureteral duplication may be accompanied by ectopia or ureterocele but if there is a partial duplication, ureters lead an orthotopic course and continues as a single common ureter up to the orifice ${ }^{8}$.

This anomaly usually remains silent but sometimes it is complicated by stenosis of the pyeloureteral transition or retrograde peristalsis or the YO-YO phenomenon, where urine spills from one ureter into another ${ }^{9}$. Geavlete $P$ et al. ${ }^{10}$ classified $Y$ junction zone morphologically into four groups as follows: double-barreled (wide bifid limbs) ureter with larger $Y$ junction, lateral insertion, punctiform insertion and valvular insertion of one of the limbs. The first type is associated with functional obstruction and the others are characterized by anatomic obstruction. Partial bifid ureter usually remains silent for that reason these patient are monitored. However sometimes ureteral stricture can be observed in lower or upper limbs of bifid ureter. In these cases some authors have recommended retrograde endoureterotomy if the ureteral stenosis of one limb is shorter than 1 $\mathrm{cm}^{10}$. In the present case patient had wide bifid limbs with larger $Y$ junction. We did not observe any ureteral stricture during the ureteroscopy so we examined both limbs of bifid $Y$ ureter up to ureteropelvic junction. We inserted 2 DJ stents for each limb of the bifid ureter to resolve the hydronephrosis caused by the functional obstruction.

During the pregnancy it is hard to make a decision about the definitive etiology of hydronephrosis because of the limited number of imaging methods performed during the pregnancy and harmful effects of $\mathrm{X}$-ray on the fetus. In some of the studies the limited 
X-ray with lower radiation doses could be used and others suggested that $x$-ray could be used with fetus shielding ${ }^{11,12}$. However Fang SM. et al. ${ }^{13}$ showed that ultrasonographic examination was able to reveal the hydronephrotic condition of all patients and URS should be preferred instead of IVP to verify the status of ureteral patency. In the present case ultrasonography failed to explain the etiology of the hydronephrosis. Diagnosis of the $Y$ type bifid ureter was made using URS. To our opinion in case of persistent renal colic and suspicious etiology of maternal hydronephrosis especially on the left side, diagnostic URS should be performed in order not to miss the diagnosis of urinary system anomalies.

First line treatment option in gestational hydronephrosis is the conservative approach such as positioning, analgesic and hydration. Double J stent placement is preferred to resolve the persistent renal colic and to prevent obstruction-related complications ${ }^{14}$.

\section{CONCLUSION}

Renal collecting system anomalies such as bifid $Y$ type ureter is a very rare diagnosis to have in mind when a pregnant patient presents with especially left side hydronephrosis. It is important to shorten delay in setting up the diagnostic ureteroscopy in order to start adequate treatment early.

\section{REFERENCES}

1. Rasmussen PE, Nielsen FR. Hydronephrosis during pregnancy: a literature survey. Eur J Obstet Gynecol Reprod Biol 1988;27(3):249-259.
https://doi.org/10.1016/0028-2243(88)90130-X

2. Charalambous $S$, Fotas $A$, Rizk DE. Urolithiasis in pregnancy.Int Urogynecol J Pelvic Floor Dysfunct 2009;20(9):1133-1136. https://doi.org/10.1007/s00192-009-0920-z

3. Dorko F, Tokarčík J, Výborná E. Congenital malformations of the ureter: anatomical studies. Anat Scilnt 2016;91(3):290294.

https://doi.org/10.1007/s12565-015-0296-8

4. Wyner LM. Late presentation of complicated complete ureteral duplication. J Urol 2015;193(3):999-1000.

https://doi.org/10.1016/j.juro.2014.12.084

5. Fiadjoe P, Kannan K, Rane A. Maternal urological problems in pregnancy. Eur J Obstet Gynecol Reprod Biol 2010;152:1317. https://doi.org/10.1016/j.ejogrb.2010.04.013

6. Boekhorst F, Bogers H, Martens J. Renal pelvis rupture during pregnancy: diagnosing a confusing source of despair. BMJ Case Rep 2015 Mar 12;2015.

7. Choi $\mathrm{Cl}, \mathrm{Yu}$ YD, Park DS. Ureteral Stent Insertion in the Management of Renal Colic during Pregnancy. Chonnam Med J 2016;52(2):123-127.

https://doi.org/10.4068/cmj.2016.52.2.123

8. Siomou E, Papadopoulou F, Kollios KD et al. Duplex collecting system diagnosed during the first 6 years of life after a first urinary tract infection: a study of 63 children. $J$ Urol 2006;175(2):678-681; discussion 681-682.

https://doi.org/10.1016/S0022-5347(05)00184-9

9. Amis ES Jr, Cronan JJ, Pfister RC. Lower moiety hydronephrosis in duplicated kidneys. Urology 1985;26(1):82-88. https://doi.org/10.1016/0090-4295(85)90268-7

10. Geavlete P, Nită G, Georgescu D, Mirciulescu V. Endoscopic classification andendo urologic therapy in proximal incomplete ureteral duplication pathology. Eur Urol 2001;39(3):304307. https://doi.org/10.1159/000052458

11. Lipsky H. Dilatation of the urinary tract during pregnancy and its management. Eur Urol 1984;10:372-376.

12. Swartz HM, Reichling BA. Hazards of radiationexposure for pregnant women. JAMA 1978;239:1907-1908. https://doi.org/10.1001/jama.1978.03280450079035

13. Fang SH, Chau K, Chow YC, Chang HK, Lin WC, Yang S. Management of symptomatic hydronephrosis during pregnancy: Experience at mackay memorial hospital. JTUA 2003;14(3):140142.

14. Çeçen K, Ülker K. The comparison of double J stent insertion and conservative treatment alone in severe pure gestational hydronephrosis: a case controlled clinical study. Scientific World Journal 2014 Jan 20;2014:989173. 